\title{
Assessment of Climate Variability for Coconut and Other Crops: A Statistical Approach
}

\author{
T.S.G. Peiris ${ }^{1}$ and J.D.J.S. Kularatne ${ }^{2}$
}

\begin{abstract}
Public opinion in Sri Lanka has been seriously concerned about the possible impact of climate change on different sectors, and in particular for the agricultural sector. Annual and weekly climate data were analyzed to provide useful information to farmers, planners and scientists to assess the suitability of different types of crops. The statistical methodology of the analysis is illustrated using daily rainfall and air temperature from 1951 to 2001 for Hambantota, a major coconut growing district in Sri Lanka. The increase in maximum air temperature and decrease in the amount of rainfall per effective rainy day (> 5mm) are the significant features of the climate variability in the Hambantota area. The warming rate for maximum air temperature was significantly higher $(p<0.005)$ than that for minimum, mean and diurnal temperature, irrespective of time scales. The annual rate of increase of maximum temperature after 1995 is $0.026^{\circ} \mathrm{C}$. The intensity of rainfall per effective rainy day $(>5 \mathrm{~mm})$ decreased significantly $(p<0.005)$. Distribution of weekly rainfall during January to September is uncertain. The probability of weekly rainfall greater than $20 \mathrm{~mm}$ does not exceed $50 \%$ in any week during this period. Long-term weekly rainfall was greater than $30 \mathrm{~mm}$ only during mid October to early December, but the probability of weekly rainfall greater than $30 \mathrm{~mm}$ exceeds $50 \%$ only during the first three weeks of November. The probability of occurrence of dry spells of duration greater than 60 days in a year is around $70 \%$, but the time of occurrence of such dry spell is not consistent among years. These findings suggest that the expected future climate would not be suitable for coconut cultivation, if growers do not apply the recommended practices to face long dry spells. Also the increasing temperature could impact to dominate plant pest during dry periods.
\end{abstract}

Keywords: Coconut, climate change, climate variability, climate analysis.

\footnotetext{
${ }^{1}$ Department of Mathematics, Faculty of Engineering, University of Moratuwa, Moratuwa, Sri Lanka. (sarathp@uom.lk)

${ }^{2}$ Biometry Division, Coconut Research Institute, Lunuwila, Sri Lanka.
} 


\section{Introduction}

Climate in a narrow sense is usually defined as the "average weather", or more rigorously, climate is the long term variability of weather parameters. The variability can be described using statistical parameters such as the mean and variance of climate variables. The climate at a given location or a region is determined by the net variability of precipitation, surface air temperature, relative humidity, sunshine duration, wind velocity and numerous other parameters (Peiris, et al, 2000). It is one of the most important limiting factors for agricultural crop production. The climate of Sri Lanka is predominantly governed by the seasonally varying monsoon system and the associated air masses that are part of the planetary wind regime over South Asia (Domroes, 1974) and thus there is a high variability in climate between different districts in Sri Lanka.

Hambantota is a rapidly urbanizing area occupying a land area of $100 \mathrm{~km}^{2}$ and is situated in the southeast of Sri Lanka between the latitudes $6.07^{\circ} \mathrm{N}$ to $6.54^{\circ} \mathrm{N}$ and the longitudes $80.64^{\circ} \mathrm{E}$ to $81.68^{\circ} \mathrm{E}$ with an altitude of $16 \mathrm{~m}$. The Hambantota area belongs to the low country high dry $\left(\mathrm{DL}_{5}\right)$ region of Sri Lanka and the $75 \%$ expectancy of annual rainfall is $1000 \mathrm{~mm}$. The economy of Hambantota depends mainly on rain fed crops and it has the greatest coconut extent of about 20000 hectares which is equivalent to $5 \%$ of the total coconut extent in Sri Lanka. In addition to coconut, rice and short term crops are grown in this area, which was one of the districts worst affected by the Tsunami of 2004. Variability in precipitation and temperature would strongly affect agricultural crops through their influences on internal plant processes and external factors such as soil water availability and pest and diseases incidence. Past analyses of rainfall in Hambantota, based on annual or monsoon seasons did not produce sufficient information on climate variability for farmers to plan their activities; Malmgren, et al., 2003). There have also been claims that the onset of monsoon rains has changed in various locations in Sri Lanka (Peiris, et al. 2000). Thus there is a need to assess the suitability of crops from time to time.
The objective of this study was therefore to demonstrate a methodology for statistical analysis of the weekly rainfall and temperature data in the Hambantota area to elucidate the past climate variability and to make inferences regarding future climate variability in the area for the purpose of planning agricultural activities.

\section{Materials and method}

\section{Climate data}

Daily data on rainfall (RF), maximum air temperature $\left(\mathrm{T}_{\mathrm{MAX}}\right)$ and minimum air temperature $\left(\mathrm{T}_{\mathrm{MIN}}\right)$ in Hambantota $\left(6.12^{\circ} \mathrm{N}\right.$, $\left.81.13^{\circ} \mathrm{E}, 16.0 \mathrm{~m}\right)$ during the period from 1951 to 2001 were acquired from the climate database of the Biometry Division of the Coconut Research Institute. Data were quality controlled and some missing daily rainfall values were estimated using exponential smoothing techniques (Malmgren et al., 2003).

\section{Statistical analysis}

Data were analyzed using SAS and Minitab statistical packages. Linear trend analysis was carried out on both yearly and weekly data for four temperature and three rainfall indices namely (i) maximum $\mathrm{T}_{\mathrm{MAX}}$, (ii) minimum $\mathrm{T}_{\mathrm{MIN}}$, (iii) mean $\left.\mathrm{T}_{\mathrm{MEA}}=\left(\mathrm{T}_{\mathrm{MAX}}+\mathrm{T}_{\mathrm{MIN}}\right) / 2\right)$, (iv) diurnal temperature $\mathrm{T}_{\mathrm{DIF}}=\left(\mathrm{T}_{\mathrm{MAX}}-\mathrm{T}_{\mathrm{MIN}}\right)$, (v) total $\mathrm{RF}$, (vi) rainfall intensity $\left(\mathrm{RF}_{\mathrm{I}}\right)$ and (vii) effective rainfall intensity $\left(\mathrm{RF}_{\mathrm{EI}}\right)$. Rainfall intensity $\left(\mathrm{RF}_{\mathrm{I}}\right)$ and effective rainfall intensity $\left(\mathrm{RF}_{\mathrm{EI}}\right)$ were defined as the amount of rainfall per rainy day $(>0 \mathrm{~mm})$ and per effective rainy day $(>5 \mathrm{~mm})$. The effective rainfall is generally subjective thing depend on the crop, however it this study it was taken as $5 \mathrm{~mm}$ as coconut is concern.

The average water requirement of adult coconut palm is 50 liters per day (Mahindapala and Pinto, 1991). Considering that the radius of the root system is approximately $2.1 \mathrm{~m}$ and the depth is $1 \mathrm{~m}$, the height of requirement of water was calculated as $5 \mathrm{~mm}$, excluding a circle of $0.30 \mathrm{~m}$ radius for the area of root ball. Thus, an 
effective rainy day for coconut can be considered as $5 \mathrm{~mm}$ per day.

To obtain weekly data, a year was divided into 52 weeks (Appendix A). In leap years rainfall on $29^{\text {th }}$ February was added to the $9^{\text {th }}$ week and converted to a 7 day total. The autocorrelation function and single spectrum density function were derived to detect any seasonal or cyclic pattern of the yearly series (Chatfield and Collins, 1980).

The non-parametric statistics $\mathrm{u}(\mathrm{t})$ and $\mathrm{u}^{\prime}(\mathrm{t})$ of Mann-Kendall rank correlation test (Turkes, et al, 2002) were used to detect any possible significant periods of trend or change points in the RF, $\mathrm{T}_{\mathrm{MAX}}, \mathrm{T}_{\mathrm{MIN}}, \mathrm{T}_{\mathrm{MEA}}$ and $\mathrm{T}_{\mathrm{DIF}}$ times series. When the value of either $u(t)$ or $u^{\prime}(t)$ is significant at the $5 \%$ level, it can be decided whether one or other trend is increasing $(\mathrm{u}(\mathrm{t})>0$ ; $\left.\mathrm{u}^{\prime}(\mathrm{t})>0\right)$ or decreasing $\left(\mathrm{u}(\mathrm{t})<0 ; \mathrm{u}^{\prime}(\mathrm{t})<0\right.$.

The length of the three longest dry spells in each year during 1951 to 2001 was computed using an SAS program. The empirical cumulative density functions for dry spells were derived to compute probabilities for the occurrence of dry spells for different lengths under normality assumption. The normality was confirmed using Anderson-Darling statistics (Chatfield and Collins, 1980).

\section{Results and discussion}

\section{Annual climate variability}

The plot of autocorrelation for all annual series confirmed that there is no cyclic pattern in the series of $\mathrm{T}_{\mathrm{MAX}}, \mathrm{T}_{\mathrm{MIN}}, \mathrm{T}_{\mathrm{MEA}}, \mathrm{T}_{\mathrm{DIF}}$ or RF. Basic statistics of four temperature and three rainfall indices were used to describe annual climate variability (Table 1).

Table 1: Basic statistics of annual indices of temperature and rainfall

\begin{tabular}{|c|c|c|c|c|}
\hline Index & Mean & CV (\%) & Minimum & Maximum \\
\hline $\mathrm{T}_{\mathrm{MAX}}\left({ }^{\circ} \mathrm{C}\right)$ & 30.39 & 1.37 & 29.37 & 31.73 \\
\hline
\end{tabular}

Annual rainfall during the 51 year period varied from $603 \mathrm{~mm}$ to $1825 \mathrm{~mm}$ with a mean of $1021 \mathrm{~mm}$. Annual variability of rainfall intensity $(\mathrm{cv}=26 \%)$ is higher than that of total rainfall $(\mathrm{cv}=25 \%)$. Variability of $\mathrm{T}_{\mathrm{DIF}}$ is significantly higher compared to other temperature indices.

\section{Maximum temperature - $\mathbf{T}_{\mathrm{MAX}}$}

Figure 1(a) clearly indicates a significant increasing trend for $\mathrm{T}_{\mathrm{MAX}}\left(\mathrm{R}^{2}=0.51 ; p<0.001\right)$ at the rate of $0.02^{\circ} \mathrm{C} /$ year. About $50 \%$ of annual variability is explained by the linear model. Figure 2(a) indicates that the significant warming trend of $\mathrm{T}_{\text {MAX }}$ commenced in 1978 . There were no periodic changes during the period 1951 to 2001. After 1978, the increasing rate of $\mathrm{T}_{\text {MAX }}$ was $0.0260^{\circ} \mathrm{C} /$ year as compared to $0.0082^{\circ} \mathrm{C} /$ year prior to 1978 .

\section{Minimum temperature - $\mathbf{T}_{\mathrm{MIN}}$}

$\mathrm{T}_{\text {MIN }}$ showed a significant increasing trend and the warming rate was $0.007^{\circ} \mathrm{C} /$ year (Figure 1.b). According to Figure 2(c) $u(t)$ exceeds the critical value during the period from 1966 to 1975 and again after 1995. The analysis also indicates that significant rates of increase and decreases commenced during 1966 and 1995 respectively. The annual rate of increase after 1995 was $0.0204^{\circ} \mathrm{C} /$ year as against $0.0042^{\circ} \mathrm{C} /$ year prior to 1995 . The $\mathrm{u}^{\prime}(\mathrm{t})$ shows no systematic trend or interaction between $u(t)$ and $u^{\prime}(t)$. No significant strong linear relationship was found between $\mathrm{T}_{\mathrm{MAX}}$ and $\mathrm{T}_{\mathrm{MIN}}(\mathrm{r}=0.658)$.

\section{Mean temperature - $\mathbf{T}_{\text {MEA }}$}

Mean temperature also showed a significant increasing trend $(\mathrm{p}<0.001)$, but the rate of increase $\left(0.0135^{\circ} \mathrm{C} /\right.$ year $)$ was less than that of $\mathrm{T}_{\mathrm{MAX}}$. The highest $\mathrm{T}_{\mathrm{MEA}}, 28.4^{\circ} \mathrm{C}$, 


\begin{tabular}{|c|c|c|c|c|}
\hline $\mathrm{T}_{\mathrm{MIN}}\left({ }^{\circ} \mathrm{C}\right)$ & 24.22 & 1.08 & 23.73 & 25.08 \\
\hline $\mathrm{T}_{\mathrm{MEA}}\left({ }^{\circ} \mathrm{C}\right)$ & 27.30 & 1.14 & 26.68 & 28.41 \\
\hline $\mathrm{T}_{\mathrm{DIF}}\left({ }^{\circ} \mathrm{C}\right)$ & 6.16 & 5.10 & 5.38 & 6.84 \\
\hline $\mathrm{RF}\left(\mathrm{mm} \mathrm{yr}^{-1}\right)$ & 1020.6 & 25.1 & 603.2 & 1825.0 \\
\hline $\mathrm{RF}_{\mathrm{I}}\left(\mathrm{mm} \mathrm{d}^{-1}\right)$ & 14.7 & 26.0 & 7.4 & 24.2 \\
\hline $\mathrm{RF}_{\mathrm{EI}}\left(\mathrm{mm} \mathrm{d}^{-1}\right)$ & 7.5 & 22.4 & 4.3 & 10.4 \\
\hline
\end{tabular}

$\mathrm{RF}_{\mathrm{I}}$ - Rainfall intensity, $\mathrm{RF}_{\mathrm{EI}}$ - effective rainfall intensity

Table 2: Increasing rates for temperature indices

\begin{tabular}{|c|c|c|c|}
\hline \multirow[b]{2}{*}{ Indicator } & \multirow[b]{2}{*}{$\begin{array}{c}\text { Year of significant } \\
\text { change }\end{array}$} & \multicolumn{2}{|c|}{ Rate of increase ( $(\mathrm{C} / \mathrm{year})$} \\
\hline & & $\begin{array}{c}\text { Prior to significant } \\
\text { change }\end{array}$ & $\begin{array}{c}\text { After the significant } \\
\text { change }\end{array}$ \\
\hline $\mathrm{T}_{\text {MAX }}$ & 1978 & 0.0082 & 0.0260 \\
\hline $\mathrm{T}_{\mathrm{MIN}}$ & 1995 & 0.0042 & 0.0204 \\
\hline $\mathrm{T}_{\text {MEA }}$ & 1983 & 0.0064 & 0.0225 \\
\hline $\mathrm{T}_{\mathrm{DIF}}$ & 1980 & 0.0119 & 0.0142 \\
\hline
\end{tabular}

Table 3: Mean and CV of the length of three longest dry spell (in days)

\begin{tabular}{|c|c|c|c|c|}
\hline Indicator & $\begin{array}{c}\text { Longest dry } \\
\text { spell }\end{array}$ & $\begin{array}{c}\mathbf{2}^{\text {nd }} \text { longest } \\
\text { dry spell }\end{array}$ & $\begin{array}{c}\mathbf{3}^{\text {rd }} \text { longest } \\
\text { dry spell }\end{array}$ & $\begin{array}{c}\text { Total of 3 dry } \\
\text { spells }\end{array}$ \\
\hline Mean & 53 & 36 & 26 & 114 \\
\hline CV (\%) & 34.6 & 25.1 & 21.4 & 28.5 \\
\hline
\end{tabular}

was recorded in 1998. There are no periodic changes for $T_{M E A}$ in Figure 2(b). Based on the pattern for $\mathrm{u}(\mathrm{t})$ (Figure 2.b) it can be confirmed that a significant change in the increasing mean temperature trend occurred in 1983. The warming rate after 1983 was $0.0225^{\circ} \mathrm{C} /$ year compared to $0.0064^{\circ} \mathrm{C} /$ year prior to 1983 .

Diurnal temperature - $\mathbf{T}_{\mathrm{DIF}}$ 
$\mathrm{T}_{\mathrm{DIF}}$ varied from $5.38^{\circ} \mathrm{C}$ (1961) to $6.84^{\circ} \mathrm{C}$ (2001). Figure 1(d) shows that the significant increment rate $(p<0.001)$ of $\mathrm{T}_{\mathrm{DIF}}$ was $0.0128^{\circ} \mathrm{C} /$ year. Both $\mathrm{u}(\mathrm{t})$ and $\mathrm{u}^{\prime}(\mathrm{t})$ intersect at 1971 (Figure 2.d) confirming that the significant change of $\mathrm{T}_{\mathrm{DIF}}$ has started during 1971, but the significant increasing trend can be seen clearly only after 1980 . The increment rate of $\mathrm{T}_{\mathrm{DIF}}$ after and prior to 1980 was $0.0142^{\circ} \mathrm{C} /$ year and $0.0119^{\circ} \mathrm{C} /$ year respectively.

The comparison of indices for increasing rates of temperature before and after the corresponding significant turning point is given in Table 2.

Based on the results in Table 2, it can be confirmed that warming rates after 1995 are significantly higher for all four temperature indices. In fact 1990-2000 has been identified as the warmest decade on record (IPCC, 2001).

\section{Rainfall - RF}

Annual rainfall shows a decreasing linear trend (Figure 3.a), but it is not significant at 5\% level. The plot of $u(t)$ and $u^{\prime}(t)$ for annual rainfall (Figure 3.b) varies within the limiting points and the two curves intersect in 1976. It confirms that there is no turning point to demonstrate significant rainfall change during 1951 to 2001. Thus, analysis of total annual rainfall is less important for climate variability in Hambantota.

\section{Rainfall intensity}

Trend analysis showed that rainfall intensity $\left(R F_{I}\right)$ and effective rainfall intensity $\left(R F_{E I}\right)$ (Figure 4) have significantly decreased with time. The rainfall intensity decreased much faster than effective rainfall intensity. During the period from 1951 to 2001 rainfall intensity has dropped from about $25 \mathrm{~mm} /$ day to about $8 \mathrm{~mm} /$ day. Corresponding rates for effective rainfall intensity were $10 \mathrm{~mm} /$ day and $5 \mathrm{~mm} /$ day.

\section{Dry spells}

Mean and coefficient of variation (CV) for the three longest dry spells and the sum of the three dry spells are shown in Table 3.

The length of the longest dry spell had the greatest variability. Based on the empirical cumulative density function shown in Figure 5 the probability of the length of the dry spell in a year being more than 60 days was $31 \%$. It implies that at least a dry spell of 60 days would occur once in three years. Figure 5 indicates that the probability of the length of the dry spell in a year being more than 65 days was $25 \%$. The probability of at least three dry spells of more than 30 days in a year was $40 \%$. The plot of the longest dry spell in a year also showed an increasing trend though it is not statistically significant. The periods of dry spells varied between the years indicating that a specific period can not be recommended for the occurrence of dry spells for all years.

\section{Weekly climate variability Weekly $\mathbf{T}_{\text {MAX }}$}

The temporal variability of long term weekly $\mathrm{T}_{\mathrm{MAX}}$ is shown in Figure 6(a). It indicates that the weekly $\mathrm{T}_{\mathrm{MAX}}$ has varied with a maximum of $31.4^{\circ} \mathrm{C}( \pm 0.09)$ during the $13^{\text {th }}$ week (26 Mar - 02 Apr) and a minimum of $29.6^{\circ} \mathrm{C}( \pm 0.11)$ during the $52^{\text {nd }}$ week $(24-31$ Dec). The temperature during the period from $9^{\text {th }}$ week to $21^{\text {st }}$ week ( 26 February to 29 May) is generally higher $\left(>31^{\circ} \mathrm{C}\right)$ than other weeks. Similarly, after the $48^{\text {th }}$ week ( $30^{\text {th }}$ November) temperature is lower than in all previous weeks. Weekly $\mathrm{T}_{\mathrm{MAX}}$ rapidly increased

Figure 1: Annual variability of $T_{M A X}, T_{M E A}$, the corresponding trend line

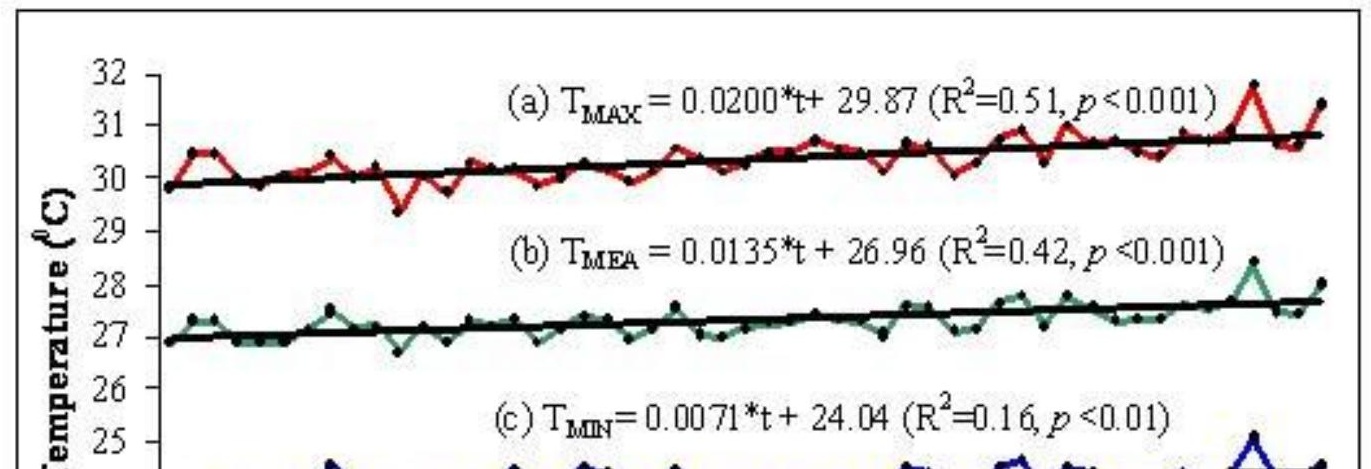


Cord 2008, 24 (1)

Figure 2: Temporal patterns of the trends in annual $\mathbf{T}_{\mathrm{MAX}}, \mathbf{T}_{\mathrm{MIN}}, \mathbf{T}_{\mathrm{MEA}}$ and $\mathbf{T}_{\mathrm{DIF}}$ temperature series and sequential values of the statistics $u(t)$ and $u^{\prime}(t)$ of the $M-K$ test with critical value of \pm 1.96 at the $5 \%$ level of significance

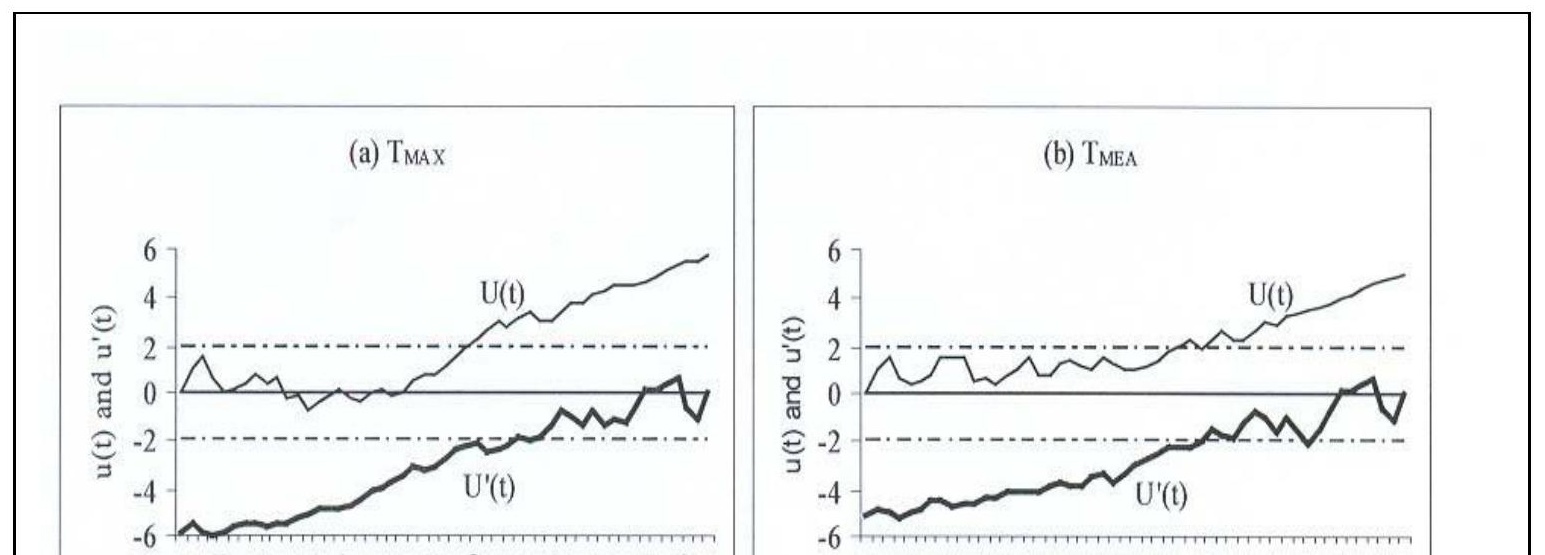


Cord 2008, 24 (1)

Figure 3: Temporal variability of (a) annual rainfall and (b) $u(t)$ and $u$ '(t) for annual rainfall

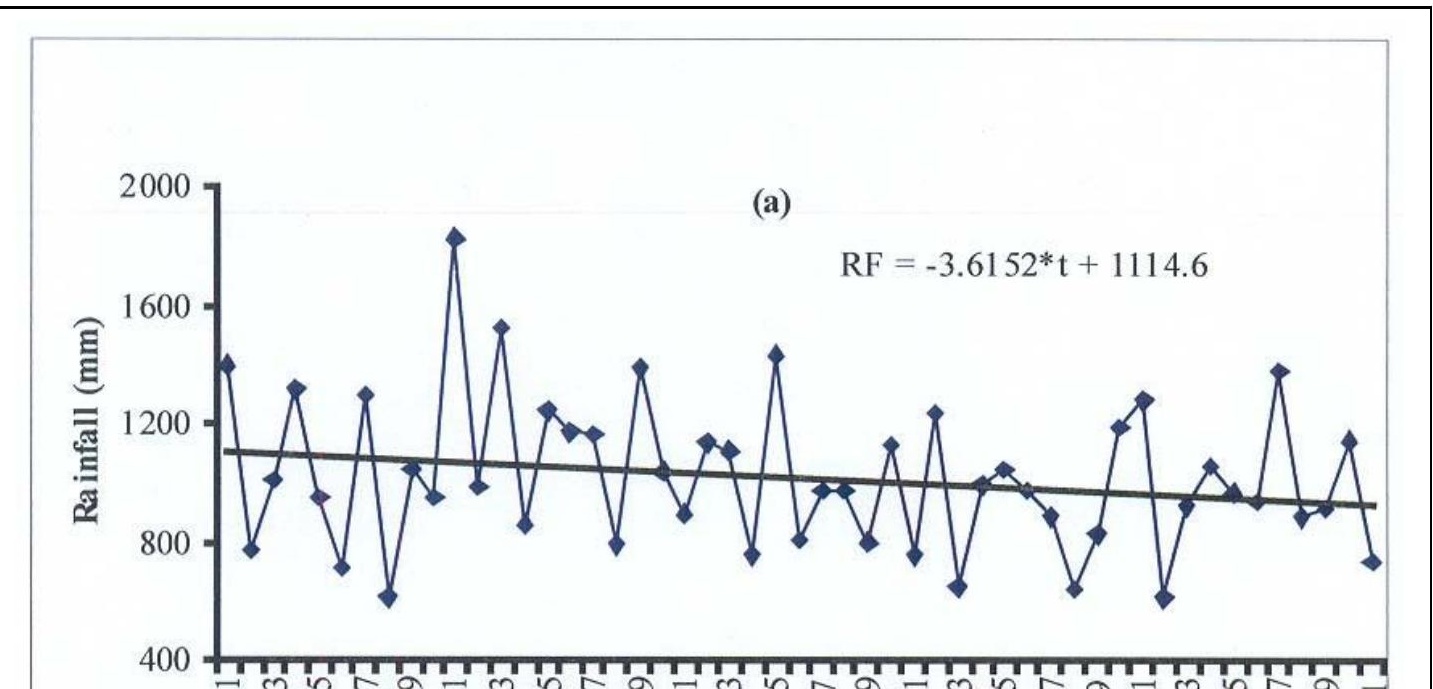


Cord 2008, $24(1)$

Figure 4: Temporal variability of (a) rainfall intensity and (b) effective rainfall intensity along with corresponding trend line

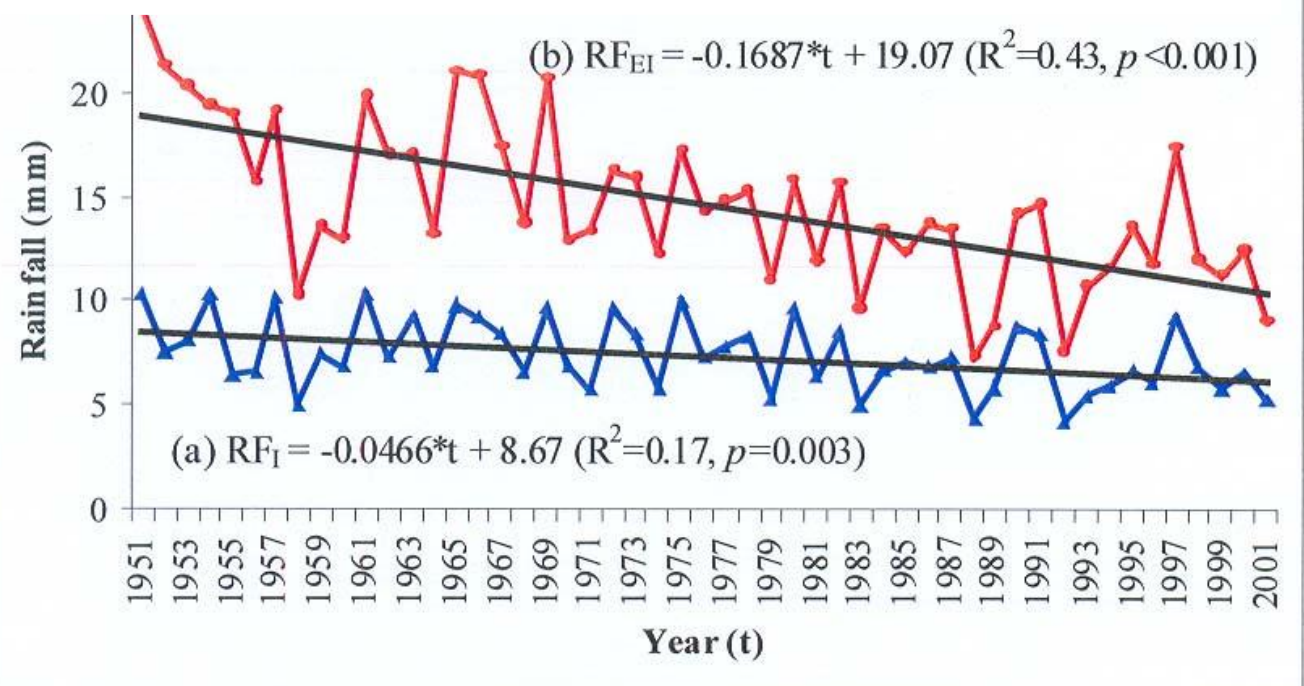


linearly from the beginning of the year until the $13^{\text {th }}$ week (6 Mar to 02 April) and subsequently decreased slowly up to the $21^{\text {st }}$ week (23-29 May) and then fluctuated around $30^{\circ} \mathrm{C}$.

The estimated parameters (b) of the linear trend model $\left(y=a+b^{*} t\right)$ fitted for each temperature index on a weekly basis is shown in Appendix B. All weeks, except the $32^{\text {nd }}$ week showed warming trends. Out of 52 weeks, 44 $(85 \%)$ showed a significant increasing trend $(p<$ $0.05)$. The rate of increase is significantly higher during the $7^{\text {th }}$ to $8^{\text {th }}$ week $(12 \mathrm{Feb}-25 \mathrm{Feb})$ and the $29^{\text {th }}$ to $30^{\text {th }}$ week (19 Jul - 01 Aug). Of these four weeks, the lowest rate of increase was observed during the $7^{\text {th }}$ week (12-18 February). As described above $5 \mathrm{~mm}$ of rainfall per day was considered as effective rainfall. Thus a 'rainy week' is defined as a week of which exceeds rainfall more than $35 \mathrm{~mm})\left(0.0322^{\circ} \mathrm{C} /\right.$ year, $p<0.01)$. Further, the period from the $9^{\text {th }}$ week (26 Feb - $04 \mathrm{Mar}$ ) to the $24^{\text {th }}$ week (13-19 Jun) also showed a high warming rate with a mean of $0.0222^{\circ} \mathrm{C} /$ year. The $52^{\text {nd }}$ week $(24-31$ December) also showed a warming rate of $0.02^{\circ} \mathrm{C} /$ year, but the mean $\mathrm{T}_{\mathrm{MAX}}$ during that week was below $29^{\circ} \mathrm{C}$.

\section{Weekly $\mathbf{T}_{\text {MIN }}$}

The pattern of temporal variability of weekly $\mathrm{T}_{\text {MIN }}$ (Figure 6.b) is not as complex as that of $\mathrm{T}_{\text {MAX }}$. Weekly $\mathrm{T}_{\text {MIN }}$ increased from $22.8^{\circ} \mathrm{C}$ $( \pm 0.14)$ during the $6^{\text {th }}$ week $(5-11 \mathrm{Feb})$ to $25.7^{\circ} \mathrm{C}$ $( \pm 0.09)$ in the $21^{\text {st }}$ week (30 May - 5 Jun) as depicted in Figure 6(b). The $\mathrm{T}_{\mathrm{MIN}}$ during the period the $15^{\text {th }}$ to the $22^{\text {nd }}$ week [dates] is higher $\left(>25^{\circ} \mathrm{C}\right)$ than in other weeks. The temperature during the $1^{\text {st }}$ to the $9^{\text {th }}$ week is lower $\left(<23.5^{\circ} \mathrm{C}\right)$ than that of other weeks. During the period from the $6^{\text {th }}$ to the $19^{\text {th }}$ week $(05 \mathrm{Feb}-15$ May) the weekly $\mathrm{T}_{\text {MIN }}$ rapidly increased with time and thereafter decreased gradually. As for $\mathrm{T}_{\mathrm{MAX}}$, all weeks except the $23^{\text {rd }}$ and $26^{\text {th }}$ weeks showed warming trends. However, only ten weeks in the year 26 Mar - 17 Apr (13-15th week), 25 Apr 08 May (17-18 ${ }^{\text {th }}$ week), 09 Nov - 29 Nov (45- $47^{\text {th }}$ week) and $21-31$ Dec (51-52 week) showed a significant increasing trend $(\mathrm{p}<0.05)$ for $\mathrm{T}_{\mathrm{MIN}}$ as shown in Appendix B. A significantly increasing trend for $\mathrm{T}_{\mathrm{MAX}}$ was also seen during the above weeks. The highest increment rate for $\mathrm{T}_{\mathrm{MIN}}$ was $0.0173^{\circ} \mathrm{C} /$ year during the $13^{\text {th }}$ and $17^{\text {th }}$ weeks $(26$ March -01 May). The rate of increase was higher for $\mathrm{T}_{\mathrm{MAX}}$ than for $\mathrm{T}_{\mathrm{MIN}}$ for all weeks and in most of the cases rate of increase for $\mathrm{T}_{\mathrm{MAX}}$ was more than double that of $\mathrm{T}_{\mathrm{MIN}}$ (Appendix $\mathrm{B}$ ).

\section{Weekly $\mathbf{T}_{\text {MEA }}$}

The mean temperature increased from the $6^{\text {th }}$ to the $20^{\text {th }}$ week $(05 \mathrm{Feb}-22$ May) and thereafter $\mathrm{T}_{\text {MEA }}$ decreased with time (Figure 6.c). The $\mathrm{T}_{\text {MEA }}$ varied with a maximum of $28.3^{\circ} \mathrm{C}( \pm 0.08)\left(19^{\text {th }}\right.$ week, 9-16 May $)$ and a minimum of $26.3^{\circ} \mathrm{C}( \pm 0.07)\left(3^{\text {rd }}\right.$ week, $15-21$ January) during the year. The trends in weekly $\mathrm{T}_{\mathrm{MEA}}$ significantly increased during the $1^{\text {st }}$ to the $18^{\text {th }}$ week (01 Jan -08 May), the $21^{\text {st }}$ to the $23^{\text {rd }}$ week (30 May-12 June), and the $28^{\text {th }}$ to the $30^{\text {th }}$ week (12 July - 01 Aug) and in almost all weeks after $12^{\text {th }}$ October. The highest rate of increase was observed in the $30^{\text {th }}$ week (26 July-01 Aug) when it was $0.0232^{\circ} \mathrm{C} /$ year.

\section{Weekly $\mathbf{T}_{\text {DIF }}$}

Figure 6(d) indicates that the temporal variation of the weekly $\mathrm{T}_{\mathrm{DIF}}$ increased from the $1^{\text {st }}$ to the $12^{\text {th }}$ week (01 Jan to $25 \mathrm{Mar}$ ). The mean diurnal temperature during the $5^{\text {th }}$ to the $12^{\text {th }}$ week $(29 \mathrm{Feb}-25 \mathrm{Mar})$ was above $7^{\circ} \mathrm{C}$. During these weeks diurnal temperature was significantly increased with time. $\mathrm{T}_{\mathrm{DIF}}$ was lowest during the $21^{\text {st }}$ and $22^{\text {nd }}$ weeks (23 May to 05 Jun) and when it was around $5^{\circ} \mathrm{C}$.

\section{Weekly RF}

The long-term weekly rainfall is shown in Appendix C. It is reasonable to assume that at least $35 \mathrm{~mm}$ of rainfall per week is required if coconut is to be grown successfully in any area 
(Mahindapala and Pinto, 1991). Appendix C shows that weekly rainfall exceeds $35 \mathrm{~mm}(5 \mathrm{~mm}$ per day) only during the period from the 42nd to the 48th week (19 Oct - 06 Dec). Analysis also showed that there is no significant increasing or decreasing trend in weekly rainfall.

Rainfall data described above using arithmetic means provide a general idea of the weekly rainfall variability. In order to develop suitable strategies for agricultural planning and implementation, it is important to have some estimates of the amount of rainfall on a weekly basis. For this purpose, the probability of receiving weekly rainfall greater than a specific amount (e.g. 0, 10, 20, 30, $35 \mathrm{~mm}$ ) was computed (Appendix C) without assuming any distribution. These threshold values were chosen to enable the user to decide upon appropriate amounts of rainfall considered as sufficient for various field operations related to agriculture. The probability of rainfall on a given week being at least $35 \mathrm{~mm}$ exceeds $50 \%$ only during the 44 th to $46^{\text {th }}$ weeks (02 Nov - 22 Nov). Similarly, the probability of rainfall on a given week being at least $30 \mathrm{~mm}$ exceeds $50 \%$ only during the $44^{\text {th }}$ to $47^{\text {th }}$ weeks
(02 Nov - 28 Nov]. These results confirm that in Hambantota, a reliable rainy spell can be expected only during the $44^{\text {th }}$-to $47^{\text {th }}$ weeks (02 Nov -28 Nov).

\section{Discussion}

All annual temperature indicators ( $\mathrm{T}_{\mathrm{MAX}}$, $\mathrm{T}_{\text {MIN }}, \mathrm{T}_{\mathrm{MEA}}$ and $\mathrm{T}_{\mathrm{DIF}}$ ) in Hambantota showed significant increasing trends $(p<0.01)$ during the period 1951-2001. The warming rate for $\mathrm{T}_{\text {MAX }}\left(0.02^{\circ} \mathrm{C} /\right.$ year $)$ is significantly higher than that for $\mathrm{T}_{\text {MIN }}\left(0.0071^{\circ} \mathrm{C} /\right.$ year $), \quad \mathrm{T}_{\text {MEA }}$ $\left(0.0135^{\circ} \mathrm{C} /\right.$ year $)$ and $\mathrm{T}_{\mathrm{DIF}}\left(0.0128^{\circ} \mathrm{C} /\right.$ year $)$. However, according to the global warming scenario the rate of $\mathrm{T}_{\mathrm{MIN}}$ is higher than that of $\mathrm{T}_{\mathrm{MAX}}$. Thus it can be hypothesized that local effects in Hambantota area are different from the global effects. The scientific reason for this different trend has to be investigated, but the low altitude and proximity to the ocean may contribute to the observed trend in temperature at Hambantota. Similar trends have been observed in parts of other coconut growing

Figure 5: Empirical cumulative density function of (a) longest spell (DS1), (b) second longest dry spell (DS2), (c) third longest dry spell (DS3) and (d) sum of the three longest dry spells
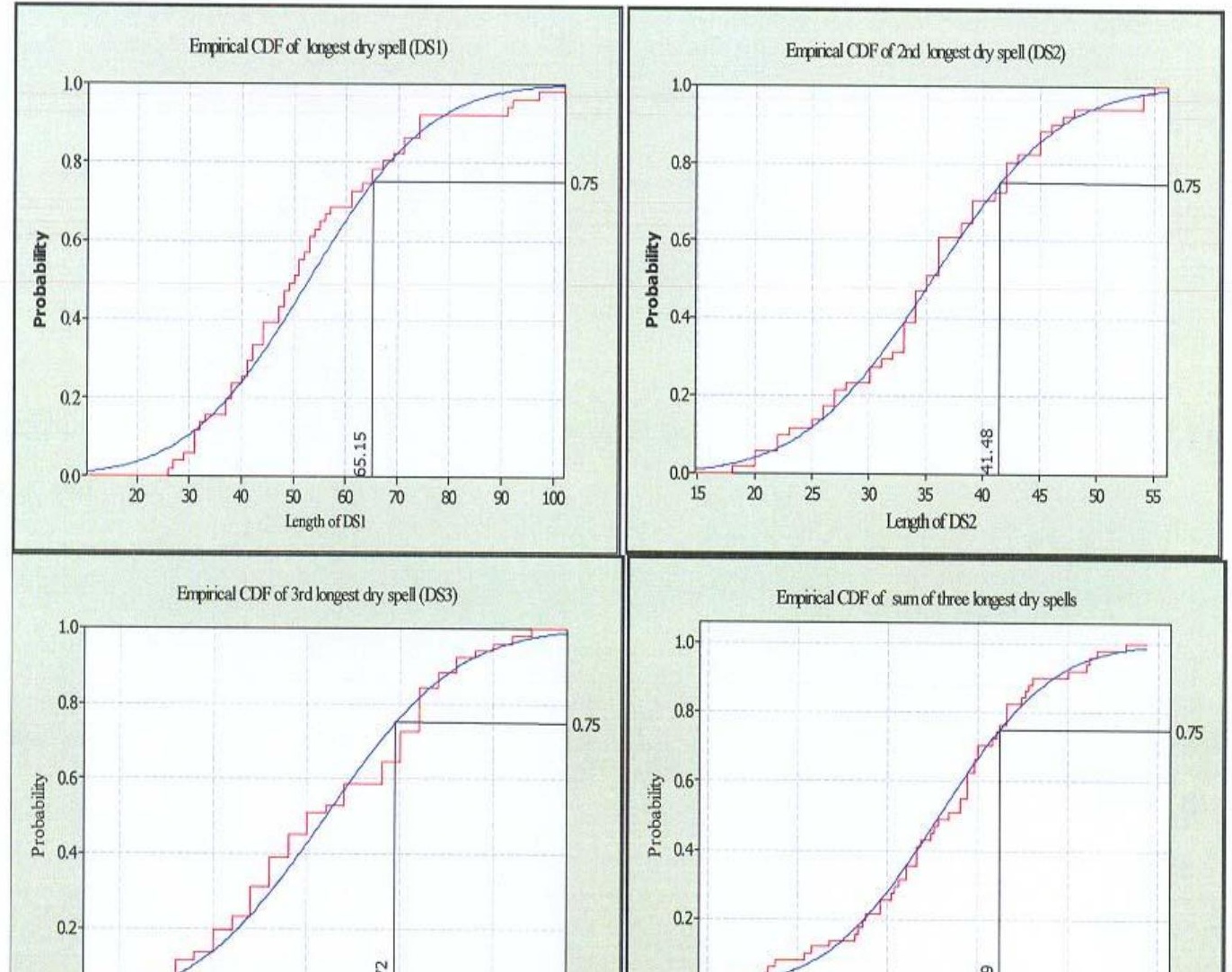
Cord 2008, 24 (1)

Figure 6: Variability of weekly temperature indices (mean $\pm \mathrm{SE}$ ) for (a) $\mathbf{T}_{\text {MAX }}$ (b) $\mathbf{T}_{\text {MIN, }}$ (c) $\mathbf{T}_{\text {MEA }}$ and (d) $\mathbf{T}_{\text {DIF }}$

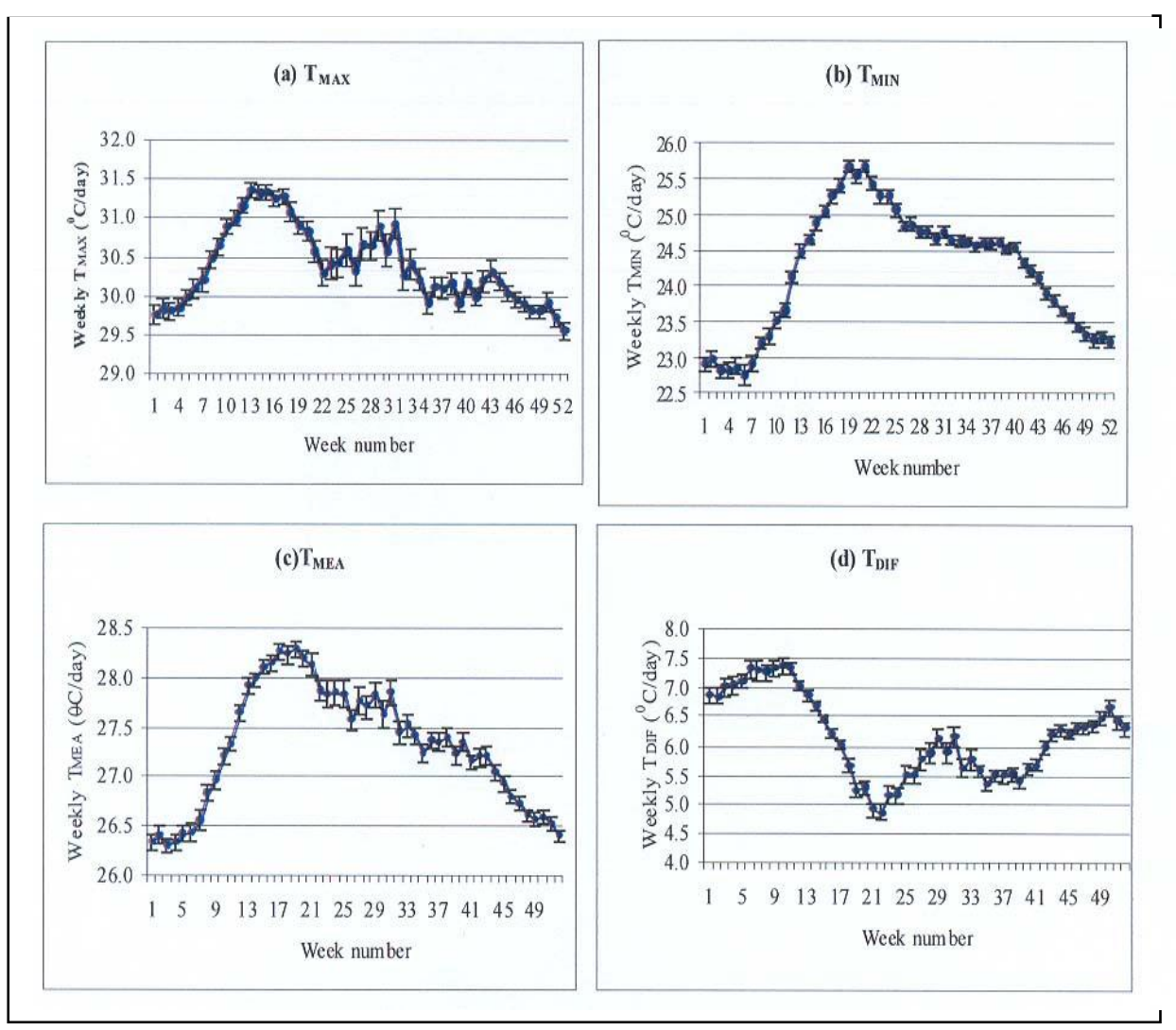


areas (Peiris, unpublished). The warming rate of $\mathrm{T}_{\mathrm{MAX}}$ is almost equal to the rate of global warming predicted by the global circulation model. As the rate of increase of $\mathrm{T}_{\mathrm{DIF}}$ is lower than that of minimum temperature, increase of warmer periods with warming during day and night could be expected in Hambantota in the future.

The increasing temperature could lead to an increased demand for water by plants. This would be a serious problem for both the agriculture and livestock industries in Hambantota. The increase of temperature in Hambantota may also be due to increased greenhouse gas concentrations in the atmosphere due to rapid urbanizing programs in the district.

Annual rainfall showed a significant negative correlation $(p<0.05)$ with maximum air temperature. Thus reduction in the annual rainfall could be expected, though it may not be statistically significant. Decrease of both rainfall intensity and effective rainfall intensity would have serious impacts on agricultural and livestock production in Hambantota. The rate of decline of the amount of effective rain is much higher than that for rainy days. Thus, less rainfall as well as lower intensity of rainfall could be expected in the future, in the Hambantota area.

The probability of dry spells of greater than 60 days in a year is $30 \%$. The probability of at least three dry spells of duration greater than 30 days in a year is $41 \%$ indicating three to four months of dry, warm weather within a year, which can occur about twice every five years. This pattern of dry spells would negatively impact on coconut as an inflorescence is produced every month. Thus the expected future climate in Hambantota will not be suitable for high coconut production. Tree crops like cashew and mango would be ideal for the Hambantota area.

Weekly rainfall showed the highest negative significant correlation with the corresponding weekly maximum air temperature. High maximum and minimum temperatures increase water demand and adversely affect planting seed material, establishment of seedlings; reduction of canopy cover and the final yield of any crop. In fact, most of the weeks, rainfall is below 25 $\mathrm{mm}$ and only the period between the 44th and 47 th weeks have a probability greater than $50 \%$ of receiving a weekly rainfall exceeding $30 \mathrm{~mm}$. This analysis suggests that the amount of rainfall in Hambantota is not sufficient to store rainwater in tanks for agricultural purposes. Use of ground water, where available, would be the only water source for both annual and perennial crops in the Hambantota area.

The highest maximum temperature $\left(>31^{\circ} \mathrm{C}\right)$ is shown generally during the $11^{\text {th }}-18^{\text {th }}$ weeks (12 Mar - 08 May) in each year. The highest diurnal temperature period also falls during the same period. The probability of weekly rainfall being greater than $25 \mathrm{~mm}$ during this period is about $10 \%$ confirming that adequate rainfall in the Hambantota area can hardly be expected during the first inter-monsoon. Therefore, this period is not suitable for planting any short term crop. Rice is one of the major crops in Hambantota. During the period from mid September $\left(38^{\text {th }}\right.$ week $)$ to end of December $\left(52^{\text {nd }}\right.$ week), the maximum temperature is below the average and the probability of weekly rainfall being greater than $35 \mathrm{~mm}$ is $50 \%$. Hence, early September is suitable for land preparation. The second inter-monsoon rains in Hambantota district commence during the $42^{\text {nd }}$ week (19-25 October) and weekly rainfall is above $35 \mathrm{~mm}$ up to the $48^{\text {th }}$ week (30 Nov $-06 \mathrm{Dec}$ ) with the rains continuing up to the $51^{\text {st }}$ or $52^{\text {nd }}$ week $\left(20^{\text {th }}\right.$ - $31^{\text {st }}$ December). Paddy planted during early September receives heavy rains during November (44th - 45th weeks) and the harvest can be obtained at the end of December or January in the dry season.

In this paper a more robust method was illustrated in to analyse various climate indicator using long-term rainfall and temperature data in a given location to derive more beneficial inferences to planners, scientists and farmers. The analysis is valid irrespective of crop. Thus more specific information can be obtained if the same techniques are applied to analyse long-term water deficits data for a 
particular crop or identify relationships between climate and crop yield. An alternative approaches to study the relationship between coconut and rainfall have been discussed by some authors (Peiris et al 2008, Peiris and Thattil, 1998).

\section{Conclusion}

In the Hambantota area of Sri Lanka, the local effects may have a stronger influence than global effects in determining long term climate variability. All annual temperature indices (maximum temperature, minimum temperature, mean temperature and diurnal temperature) and weekly maximum temperature showed significant increasing trends. Rates of increase are higher since 1995. The amount of rainfall per rainy day $(>0 \mathrm{~mm})$ and that per effective rainy day (> 5 $\mathrm{mm})$ declined significantly over the period between 1951 and 2001. Rainfall and maximum temperature showed a significant negative relationship. The probability of occurrence of a dry spell of more than 60 days duration is $30 \%$. However, the time of the year during which a longer dry spell could occur is not consistent between years. The rate of increase of weekly maximum air temperature is higher than that of weekly minimum air temperature in all weeks in a year. Alternative methods to obtain water such as exploration of ground water are necessary, if agriculture is to be promoted in the Hambantota area in the future. The results derived from this study provide important information on climate variability in Hambantota which have policy implications. These results could also be considered during implementation of crop insurance programs to protect farmers. Similar analysis of weekly rainfall of long-term data is recommended to understand the expected climate variability in any other areas.

\section{Acknowledgments}

The project was supported by the Assessment of Impacts of and Adaptation to Climate Change program (AS12) managed by the International START Secretariat and sponsored by the United Nations Environment Program and the Third World Academy of Sciences and Junior
Research Project of the Ministry of Environment \& Natural Resources, in Sri Lanka. The authors wish to thank Dr. Janaka Ratnasiri, National Coordinator of the AS12 project and Dr. (Mrs.) C. Jayasekara, Director of the Coconut Research Institute (CRI) for their support. A special thanks to Udula of the Biometry Division for her assistance in editing and page making while the main author was in CRI.

\section{References}

Chatfield, C. and Collins, A. J. 1980. Introduction to Time Series Analysis. Chapman and Hall, London.

Domroes, M. 1974. The Agro climate of Ceylon, Franz Steiner, Verlag, Wiesbaden, Germany.

IPCC, 2001. Climate change, summary for policymakers: A report of working Group I of the Intergovernmental Panel on Climate Change, Cambridge University Press, Cambridge.

Kendall, M. 1976. Time Series Analysis (2 ${ }^{\text {nd }}$ Edition). Charles Griffin and Company Ltd, London.

Mahindapala, R., Pinto, J.L.J.G., (1991), Coconut cultivation, CRI, Lunuwila.

Malmgren, B. A., Hulugalla, R, Hayashi, Y. and Mikami, T. 2003. Precipitation Trends in Sri Lanka since 1870 and relationship to el-nino - southern oscillation. Inernational Journal of Climatology 23: $1235-1252$.

Peiris, T. S. G. and Thattil, R. O. (1998). The study of climate effects on the nut yield of coconut using parsimonious models. J. of Experimental Agriculture 34: 189-206.

Peiris, T.U.S., Peiris, T.S.G. and Samita, S. 2000. Arrival of South-west monsoon rains. Tropical Agricultural Research 12: 265-275. 
Peiris, T. S. G., Hansen, J. W and Lareef, Zubair (2008). Use of seasonal climate information to predict coconut production in Sri Lanka. International. $J$ of Climatology 28: 103-10

Turkes, M., Sumer, U. M. and Demir, I. 2002. Re-evaluation of trends and changes in mean, maximum and minimum temperatures of Turkey for the period
1929-1999. International Journal Climatology 22: 947-977.

Widyarathne, K.P, Peiris, T.S.G. and Samita, S. 2006 Shift In Onset Of First Inter Monsoon Rain In Coconut Growing Areas In Sri Lanka. Tropical Agricultural Research 18: 1-12.

\section{Appendix A}

The periods corresponding to the week numbers

\begin{tabular}{|c|c|c|c|}
\hline Week No & $\begin{array}{l}\text { Weekly Period } \\
\text { (dates) }\end{array}$ & Week No & $\begin{array}{c}\text { Weekly Period } \\
\text { (dates) }\end{array}$ \\
\hline 1 & $01-07$ Jan & 27 & $05-11 \mathrm{Jul}$ \\
\hline 2 & $08-14$ Jan & 28 & $12-18 \mathrm{Jul}$ \\
\hline 3 & $15-21$ Jan & 29 & $19-25 \mathrm{Jul}$ \\
\hline 4 & $22-28$ Jan & 30 & $26 \mathrm{Jul}-01 \mathrm{Aug}$ \\
\hline 5 & $29 \mathrm{Jan}-04 \mathrm{Feb}$ & 31 & 02-08 Aug \\
\hline 6 & $05-11$ Feb & 32 & $09-15$ Aug \\
\hline 7 & $12-18$ Feb & 33 & $16-22$ Aug \\
\hline 8 & $19-25 \mathrm{Feb}$ & 34 & $23-29$ Aug \\
\hline 9 & $26 \mathrm{Feb}-04 \mathrm{Mar}$ & 35 & $30 \mathrm{Aug}-05 \mathrm{Sep}$ \\
\hline 10 & $05-11 \mathrm{Mar}$ & 36 & $06-12$ Sep \\
\hline 11 & $12-18 \mathrm{Mar}$ & 37 & $13-19$ Sep \\
\hline 12 & $19-25 \mathrm{Mar}$ & 38 & $20-27$ Sep \\
\hline 13 & $26 \mathrm{Mar}-02 \mathrm{Apr}$ & 39 & $28 \mathrm{Sep}-04 \mathrm{Oct}$ \\
\hline 14 & $03-09$ Apr & 40 & $05-11$ Oct \\
\hline 15 & $10-17$ Apr & 41 & $12-18$ Oct \\
\hline 16 & $18-24$ Apr & 42 & $19-25$ Oct \\
\hline 17 & 25 Apr - 01 May & 43 & 26 Oct $-01 \mathrm{Nov}$ \\
\hline 18 & $02-08$ May & 44 & $02-08 \mathrm{Nov}$ \\
\hline 19 & 09 - 15 May & 45 & $09-15 \mathrm{Nov}$ \\
\hline
\end{tabular}




\begin{tabular}{|c|c|c|c|}
\hline 20 & $16-22$ May & 46 & $16-22$ Nov \\
\hline 21 & $23-29$ May & 47 & $23-29$ Nov \\
\hline 22 & 30 May -05 Jun & 48 & 30 Nov -06 Dec \\
\hline 23 & $06-12$ Jun & 49 & $07-13$ Dec \\
\hline 24 & $13-19$ Jun & 50 & $14-20$ Dec \\
\hline 25 & $20-27$ Jun & 51 & $21-23 \mathrm{Dec}$ \\
\hline 26 & 28 Jun-04 Jul & 52 & $24-31 \mathrm{Dec}$ \\
\hline
\end{tabular}

Appendix B

Warming rates ( $\left.{ }^{\circ} \mathrm{C} / \mathrm{year}\right)$ of the temperature indices by weeks

\begin{tabular}{|c|c|c|c|c|}
\hline $\begin{array}{l}\text { Week } \\
\text { number }\end{array}$ & $\mathrm{T}_{\mathrm{MAX}}$ & $\mathrm{T}_{\mathrm{MIN}}$ & $\mathrm{T}_{\text {MEA }}$ & $\mathrm{T}_{\mathrm{DIF}}$ \\
\hline 1 & $0.0142 *$ & $0.0100 \mathrm{~ns}$ & $0.0121 *$ & $0.0042 \mathrm{~ns}$ \\
\hline 2 & $0.0243 * *$ & $0.0101 \mathrm{~ns}$ & $0.0172 *$ & $0.0143 *$ \\
\hline 3 & $0.0232 * *$ & $0.0086 \mathrm{~ns}$ & $0.0159 *$ & $0.0146 *$ \\
\hline 4 & $0.0279 * * *$ & $0.0079 \mathrm{~ns}$ & $0.0180 * * *$ & 0.0201 \\
\hline 5 & $0.0161 *$ & $0.0145 *$ & $0.0153 * *$ & $0.0016 \mathrm{~ns}$ \\
\hline 6 & $0.0221 * *$ & $0.0114 \mathrm{~ns}$ & $0.0167 *$ & $0.0107 \mathrm{~ns}$ \\
\hline 7 & $0.0322 * * *$ & $0.0099 \mathrm{~ns}$ & $0.0210 * *$ & 0.0223 \\
\hline 8 & $0.0338 * * *$ & $0.0045 \mathrm{~ns}$ & $0.0191 *$ & $0.0293 * *$ \\
\hline 9 & $0.0242 * *$ & $0.0085 \mathrm{~ns}$ & $0.0162 * *$ & $0.0154 *$ \\
\hline 10 & $0.0148 \quad *$ & $0.0022 \mathrm{~ns}$ & $0.0085 \mathrm{~ns}$ & $0.0126 \mathrm{~ns}$ \\
\hline 11 & $0.0161 * *$ & $0.0076 \mathrm{~ns}$ & $0.0119 *$ & $0.0085 \mathrm{~ns}$ \\
\hline 12 & $0.0184 * *$ & $0.0095 \mathrm{~ns}$ & $0.0139 *$ & $0.0089 \mathrm{~ns}$ \\
\hline 13 & $0.0270 * * *$ & $0.0173 *$ & $0.0222 * *$ & $0.0097 \mathrm{~ns}$ \\
\hline 14 & $0.0183 * *$ & $0.0117 *$ & $0.0150 * *$ & $0.0065 \mathrm{~ns}$ \\
\hline 15 & $0.0180 * *$ & $0.0168 *$ & $0.0174 * * *$ & $0.0012 \mathrm{~ns}$ \\
\hline 16 & $0.0204 * *$ & $0.0102 \mathrm{~ns}$ & $0.0152 * *$ & $0.0101 *$ \\
\hline 17 & $0.0199 *$ & $0.0173 * *$ & $0.0186 * *$ & $0.0025 \mathrm{~ns}$ \\
\hline 18 & $0.0212 * *$ & $0.0128 *$ & $0.0170 * *$ & 0.0083 \\
\hline 19 & $0.0099 \mathrm{~ns}$ & $0.0042 \mathrm{~ns}$ & $0.0071 \mathrm{~ns}$ & 0.0056 \\
\hline
\end{tabular}




\begin{tabular}{|c|c|c|cc|rc|}
\hline 20 & $0.0048 \mathrm{~ns}$ & $0.0043 \mathrm{~ns}$ & $0.0046 \mathrm{~ns}$ & 0.0004 & $\mathrm{~ns}$ \\
\hline 21 & $0.0273 * *$ & $0.0112 \mathrm{~ns}$ & 0.0192 & $* *$ & 0.0161 & $*$ \\
\hline 22 & $0.0275 * *$ & $0.0011 \mathrm{~ns}$ & 0.0143 & $*$ & 0.0264 & $* *$ \\
\hline 23 & $0.0260 * *$ & $-0.0047 \mathrm{~ns}$ & $0.0106 \mathrm{~ns}$ & 0.0306 & $* * *$ \\
\hline 24 & $0.0229 * *$ & $0.0017 \mathrm{~ns}$ & $0.0123 \mathrm{~ns}$ & 0.0211 & $*$ \\
\hline 25 & $0.0167 *$ & $0.0103 \mathrm{~ns}$ & $0.0136 \mathrm{~ns}$ & 0.0064 & $\mathrm{~ns}$ \\
\hline 26 & $0.0168 *$ & $-0.0026 \mathrm{~ns}$ & $0.0070 \mathrm{~ns}$ & 0.0195 & $\mathrm{~ns}$ \\
\hline
\end{tabular}

$(*-\mathbf{p}<0.05, * *-\mathbf{p}<0.01, * * *-\mathbf{p}<0.001$, ns -not significant $)$

\section{Appendix B (Continued)}

Warming rates $\left({ }^{0} \mathrm{C} / \mathrm{year}\right)$ of the temperature indices by weeks

\begin{tabular}{|c|c|c|c|c|c|}
\hline $\begin{array}{l}\text { Week } \\
\text { number }\end{array}$ & $\mathrm{T}_{\mathrm{MAX}}$ & $\mathrm{T}_{\mathrm{MIN}}$ & & $\mathrm{T}_{\mathrm{MEA}}$ & $\mathrm{T}_{\mathrm{DIF}}$ \\
\hline 27 & 0.0207 ** & $0.0030 \mathrm{n}$ & & $0.0119 \mathrm{~ns}$ & $0.0179 \mathrm{~ns}$ \\
\hline 28 & $0.0273 *$ & $0.0018 \mathrm{n}$ & & $0.0144 *$ & 0.0249 \\
\hline 29 & 0.0345 *** & $0.0057 \mathrm{n}$ & & 0.0201 & 0.0288 \\
\hline 30 & 0.0392 *** & $0.0074 \mathrm{n}$ & & $0.0232 * *$ & 0.0320 ** \\
\hline 31 & $0.0173 *$ & $0.0057 \mathrm{n}$ & & $0.0116 \mathrm{~ns}$ & $0.0117 \mathrm{~ns}$ \\
\hline 32 & $-0.0074 \mathrm{~ns}$ & $0.0000 \mathrm{n}$ & & $-0.0038 \mathrm{~ns}$ & -0.0077 \\
\hline 33 & $0.0197 *$ & $0.0016 \mathrm{n}$ & & $0.0102 \mathrm{~ns}$ & $0.0171 \mathrm{~ns}$ \\
\hline 34 & $0.0085 \mathrm{~ns}$ & $0.0014 \mathrm{n}$ & & $0.0055 \mathrm{~ns}$ & $0.0080 \mathrm{~ns}$ \\
\hline 35 & 0.0227 ** & -0.0007 & ns & $0.0108 \mathrm{~ns}$ & 0.0231 ** \\
\hline 36 & $0.0047 \mathrm{~ns}$ & $0.0000 \mathrm{n}$ & & $0.0025 \mathrm{~ns}$ & $0.0049 \mathrm{~ns}$ \\
\hline 37 & $0.0191 *$ & $0.0044 \mathrm{n}$ & & $0.0118 \mathrm{~ns}$ & $0.0147 \mathrm{~ns}$ \\
\hline 38 & 0.0275 ** & $0.0032 \mathrm{n}$ & & 0.0152 ** & 0.0243 ** \\
\hline 39 & $0.0223 *$ & $0.0033 \mathrm{n}$ & & $0.0127 \mathrm{~ns}$ & 0.0188 \\
\hline 40 & $0.0190 * *$ & $0.0014 \mathrm{n}$ & & $0.0102 \mathrm{~ns}$ & 0.0176 \\
\hline 41 & $0.0200 * *$ & $0.0051 \mathrm{n}$ & & 0.0125 ** & 0.0149 \\
\hline 42 & $0.0265 * *$ & $0.0086 \mathrm{n}$ & $\mathrm{ns}$ & 0.0175 ** & 0.0178 \\
\hline 43 & 0.0186 & $0.0019 \mathrm{n}$ & ns & $0.0102 \mathrm{~ns}$ & 0.0167 \\
\hline 44 & $0.0266 * *$ & $0.0080 \mathrm{n}$ & & $0.0173 *$ & 0.0186 ** \\
\hline
\end{tabular}




\begin{tabular}{|c|c|c|c|c|}
\hline 45 & 0.0139 & $0.0127 * *$ & $0.0134 *$ & $0.0010 \mathrm{~ns}$ \\
\hline 46 & 0.0135 & $0.0143 *$ & $0.0140 *$ & $-0.0007 \mathrm{~ns}$ \\
\hline 47 & 0.0164 & 0.0109 * & $0.0135 *$ & $0.0059 \mathrm{~ns}$ \\
\hline 48 & 0.0150 & $0.0066 \mathrm{n}$ & 0.0108 & $0.0083 \mathrm{~ns}$ \\
\hline 49 & $0.0111 \mathrm{n}$ & $0.0070 \mathrm{n}$ & 0.0095 & $0.0031 \mathrm{~ns}$ \\
\hline 50 & $0.0106 \mathrm{n}$ & $0.0095 \mathrm{n}$ & 0.0101 & $0.0012 \mathrm{~ns}$ \\
\hline 51 & $0.0046 \mathrm{n}$ & $0.0154 *$ & 0.0100 & $-0.0108 \mathrm{~ns}$ \\
\hline 52 & $0.0218 *$ & 0.0114 & $0.0166 *$ & $0.0104 \mathrm{~ns}$ \\
\hline
\end{tabular}

$(*-\mathrm{p}<0.05, * *-\mathrm{p}<0.01, * * *-\mathrm{p}<0.001$, ns -not significant $)$

Appendix C

Mean rainfall and probability $(\%)$ of rainfall greater than $0,10,20,30,35 \mathrm{~mm}$ by weeks

\begin{tabular}{|c|c|c|c|c|c|c|}
\hline \multirow{2}{*}{$\begin{array}{l}\text { Week } \\
\text { number }\end{array}$} & \multirow{2}{*}{$\begin{array}{l}\text { Amount of } \\
\text { rainfall }(\mathrm{mm})\end{array}$} & \multicolumn{5}{|c|}{ Probabilities (\%) of rainfall } \\
\hline & & $>0 \mathrm{~mm}$ & $>10 \mathrm{~mm}$ & $>20 \mathrm{~mm}$ & $>30 \mathrm{~mm}$ & $>35 \mathrm{~mm}$ \\
\hline 1 & 18.5 & 74.51 & 37.25 & 31.37 & 25.49 & 17.65 \\
\hline 2 & 19.4 & 80.39 & 43.14 & 27.45 & 21.57 & 21.57 \\
\hline 3 & 22.9 & 64.71 & 39.22 & 29.41 & 19.61 & 17.65 \\
\hline 4 & 10.7 & 56.86 & 29.41 & 23.53 & 9.80 & 9.80 \\
\hline 5 & 16.8 & 62.75 & 35.29 & 29.41 & 21.57 & 15.69 \\
\hline 6 & 13.1 & 52.94 & 37.25 & 23.53 & 19.61 & 19.61 \\
\hline 7 & 10.8 & 54.90 & 29.41 & 17.65 & 13.73 & 13.73 \\
\hline 8 & 11.9 & 54.90 & 29.41 & 21.57 & 9.80 & 7.84 \\
\hline 9 & 14.7 & 56.86 & 31.37 & 23.53 & 13.73 & 11.76 \\
\hline 10 & 11.4 & 56.86 & 29.41 & 13.73 & 9.80 & 7.84 \\
\hline 11 & 13.5 & 58.82 & 33.33 & 21.57 & 13.73 & 9.80 \\
\hline 12 & 11.4 & 58.82 & 25.49 & 13.73 & 9.80 & 7.84 \\
\hline 13 & 15.1 & 70.59 & 33.33 & 25.49 & 21.57 & 13.73 \\
\hline 14 & 22.1 & 84.31 & 54.90 & 33.33 & 29.41 & 23.53 \\
\hline 15 & 22.5 & 74.51 & 58.82 & 37.25 & 27.45 & 23.53 \\
\hline 16 & 22.6 & 82.35 & 45.10 & 33.33 & 21.57 & 19.61 \\
\hline 17 & 19.1 & 84.31 & 50.98 & 37.25 & 19.61 & 17.65 \\
\hline 18 & 25.1 & 88.24 & 56.86 & 41.18 & 27.45 & 21.57 \\
\hline 19 & 18.9 & 76.47 & 39.22 & 31.37 & 23.53 & 17.65 \\
\hline 20 & 20.8 & 76.47 & 52.94 & 35.29 & 31.37 & 25.49 \\
\hline 21 & 12.4 & 74.51 & 33.33 & 23.53 & 11.76 & 9.80 \\
\hline 22 & 15.4 & 88.24 & 33.33 & 25.49 & 19.61 & 17.65 \\
\hline
\end{tabular}


Cord 2008, 24 (1)

\begin{tabular}{|l|l|l|l|l|l|l|}
23 & 11.4 & 82.35 & 39.22 & 15.69 & 7.84 & 7.84 \\
\hline 24 & 13.2 & 78.43 & 29.41 & 19.61 & 11.76 & 11.76 \\
\hline 25 & 12.9 & 78.43 & 33.33 & 25.49 & 17.65 & 17.65 \\
\hline 26 & 13.1 & 78.43 & 35.29 & 17.65 & 11.76 & 11.76 \\
\hline 27 & 10.1 & 68.63 & 25.49 & 9.80 & 7.84 & 7.84 \\
\hline 28 & 8.1 & 72.55 & 27.45 & 11.76 & 5.88 & 5.88 \\
\hline 29 & 12.7 & 70.59 & 33.33 & 19.61 & 13.73 & 9.80 \\
\hline 30 & 12.2 & 72.55 & 33.33 & 17.65 & 13.73 & 9.80 \\
\hline 31 & 9.8 & 58.82 & 23.53 & 19.61 & 13.73 & 9.80 \\
\hline
\end{tabular}

Appendix C (Contd)

Mean rainfall and probability $(\%)$ of rainfall greater than $0,10,20,30,35 \mathrm{~mm}$ by weeks

\begin{tabular}{|c|c|c|c|c|c|c|}
\hline \multirow{2}{*}{$\begin{array}{l}\text { Week } \\
\text { number }\end{array}$} & \multirow{2}{*}{$\begin{array}{l}\text { Amount of } \\
\text { rainfall }(\mathrm{mm})\end{array}$} & \multicolumn{5}{|c|}{ Probabilities $(\%)$ of rainfall } \\
\hline & & $>0 \mathrm{~mm}$ & $>10 \mathrm{~mm}$ & $20 \mathrm{~mm}$ & $>30 \mathrm{~mm}$ & $>35 \mathrm{~mm}$ \\
\hline 32 & 15.3 & 80.39 & 39.22 & 27.45 & 19.61 & 19.61 \\
\hline 33 & 14.8 & 68.63 & 37.25 & 21.57 & 11.76 & 11.76 \\
\hline 34 & 7.3 & 60.78 & 27.45 & 11.76 & 5.88 & 3.92 \\
\hline 35 & 10.0 & 68.63 & 29.41 & 17.65 & 13.73 & 9.80 \\
\hline 36 & 7.4 & 70.59 & 21.57 & 5.88 & 3.92 & 3.92 \\
\hline 37 & 16.3 & 78.43 & 47.06 & 27.45 & 17.65 & 11.76 \\
\hline 38 & 19.7 & 86.27 & 49.02 & 29.41 & 19.61 & 17.65 \\
\hline 39 & 22.1 & 86.27 & 52.94 & 31.37 & 19.61 & 17.65 \\
\hline 40 & 15.1 & 74.51 & 35.29 & 25.49 & 23.53 & 19.61 \\
\hline 41 & 26.0 & 82.35 & 54.90 & 43.14 & 33.33 & 25.49 \\
\hline 42 & 35.6 & 80.39 & 58.82 & 47.06 & 37.25 & 35.29 \\
\hline 43 & 36.0 & 90.20 & 64.71 & 54.90 & 39.22 & 35.29 \\
\hline 44 & 50.0 & 98.04 & 78.43 & 66.67 & 54.90 & 54.90 \\
\hline 45 & 45.4 & 98.04 & 78.43 & 66.67 & 56.86 & 49.02 \\
\hline 46 & 49.9 & 100.00 & 82.35 & 66.67 & 54.90 & 54.90 \\
\hline 47 & 38.0 & 98.04 & 78.43 & 66.67 & 50.98 & 39.22 \\
\hline
\end{tabular}


Cord 2008, 24 (1)

\begin{tabular}{|c|c|c|c|c|c|c|}
\hline 48 & 38.8 & 96.08 & 74.51 & 60.78 & 49.02 & 45.10 \\
\hline 49 & 21.8 & 88.24 & 54.90 & 39.22 & 23.53 & 23.53 \\
\hline 50 & 24.3 & 86.27 & 49.02 & 39.22 & 27.45 & 23.53 \\
\hline 51 & 24.7 & 90.20 & 52.94 & 35.29 & 23.53 & 21.57 \\
\hline 52 & 26.2 & 90.20 & 47.06 & 31.37 & 23.53 & 19.61 \\
\hline
\end{tabular}

